\title{
PUBLIC HEALTH RESEARCH
}

\section{Physical Inactivity and Its Associated Factors among Adults in Malaysia: Findings from National Health and Morbidity Survey (NHMS) 2019}

Nazirah Alias, ${ }^{1 *}$ Chan Ying Ying, ${ }^{2}$ Lim Kuang Kuay, ${ }^{3}$ Ahzairin Ahmad, ${ }^{4}$ Halizah Mat Rifin, ${ }^{5}$ Nik Adilah Shahein ${ }^{2}$ and Azli Baharudin ${ }^{6}$

${ }^{1}$ Centre for Burden of Disease Research, Institutefor Public Health, National Institutes of Health, Malaysia.

${ }^{2}$ Centre for Family Health Research, Institute for Public Health, National Institutes of Health, Malaysia.

${ }^{3}$ Centre for Occupational Health Research, Institute for Public Health, National Institutes of Health, Malaysia

${ }^{4}$ Surveillance Unit, Disease Control Department, MinistryofHealth, Malaysia.

${ }^{5}$ Centre for Non Communicable Diseases Research, Institute for Public Health, National Institutes of Health, Malaysia.

${ }^{6}$ Centre for Nutrition Epidemiology Research, Institute for Public Health, National Institutes of Health, Malaysia.

*For reprint and all correspondence: Nazirah Alias, Institute for Public Health, Block B5 \& B6, National Institutes of Health, No. 1 Jalan Setia Murni U13/52, Seksyen U13 Setia Alam, 40170 Shah Alam, Selangor, Malaysia.

Email:nazirah.alias@moh.gov.my

ABSTRACT

\begin{tabular}{|c|c|}
\hline Introduction & $\begin{array}{l}\text { Physical inactivity has been identified as the fourth leading risk factor for } \\
\text { worldwide mortality with major implications towards general health. } \\
\text { Monitoring the level of physical inactivity may reduce the burden of non- } \\
\text { communicable diseases (NCDs) and their risk factors. This study aims to } \\
\text { determine the prevalence of physical inactivity and its ass ociated factors } \\
\text { among adults aged } 18 \text { years and above in Malaysia. }\end{array}$ \\
\hline Methods & $\begin{array}{l}\text { Data was obtained from the National Health and Morbidity Survey (NHMS) } \\
2019 \text {. It was a cros s-sectional, population-based survey which employed two- } \\
\text { stage stratified random sampling design. A total of } 10,356 \text { out of } 10,472 \\
\text { respondents were interviewed using a short version of International Physical } \\
\text { Activity Questionnaire (IPAQ). }\end{array}$ \\
\hline Res ults & $\begin{array}{l}\text { Overall, the prevalence of physical inactivity among adults aged } 18 \text { years and } \\
\text { above in Malaysia was } 24.6 \%(95 \% \text { CI: } 23.2,26.1) \text {. Results frommultivariable } \\
\text { logistic model showed that Chinese ethnicity (aOR } 1.32 ; 95 \% \text { CI: } 1.04,1.67) \text {, } \\
\text { urban dwellers (aOR } 1.30 ; 95 \% \text { CI: } 1.07,1.57) \text {, those who were single } \\
\text { (including widow, widower and divorcee) (aOR } 1.36 ; 95 \% \text { CI: } 1.14,1.61) \text {, } \\
\text { students (aOR } 2.10 ; 95 \% \mathrm{CI}: 1.30,3.40) \text {, higher household income earners } \\
\text { (aOR } 1.34 ; 95 \% \text { CI: } 1.07,1.68) \text { and those with hypercholesterolaemia (aOR } \\
1.25 ; 95 \% \text { CI: } 1.03,1.51) \text { were significantly more likely to be physically } \\
\text { inactive. }\end{array}$ \\
\hline Conclusions & $\begin{array}{l}\text { Specific and appropriate intervention towards targeted group is in crucialneed } \\
\text { to increase the level of physical activity and to promote an active living } \\
\text { towards an active and healthy Malaysia. }\end{array}$ \\
\hline y wor us & bycicolingetivity IDAO NHMS 2010 Molaycis \\
\hline
\end{tabular}

Article history:

Received: 7December 2021

Accepted: 14December 2021

Published: 1 March 2022 


\section{INTRODUCTION}

Physical inactivity has been identified as the fourth leading risk factor for worldwide mortality with major implications towards general health, including increasing prevalence of noncommunicable diseases (NCDs) such as cardiovascular disease, diabetes, cancer and NCD risk factors such as raised blood pressure, raised blood sugar and overweight. ${ }^{1}$ It is estimated that physical inactivity causes major NCDs with approximately $6 \%$ of coronary heart disease, $7 \%$ of type 2 diabetes, $10 \%$ of breast cancer and $10 \%$ of colon cancer, with $9 \%$ of premature mortality in 2008 worldwide. $^{2}$

Globally, the prevalence of insufficient physical activity in adults aged 18 years and older were $27.5 \%$ (95\% Uncertainty Interval (UI) 25.0 $32.2)$; with $36.8 \%$ (95\% UI 34.6 - 38.4) in highincome Western Countries, 39.1\% (95\% UI $37.8-$ 40.6) in Latin America and Caribbean, and 17.3\% (95\% UI $15.8-22.1)$ in east and southeast Asia, doubling in high-income countries compared to lowincome countries in 2016. ${ }^{3}$ An International Prevalence Study on Physical Activity(IPS) showed that low physical activity ranged from $6.9 \%$ to $43.3 \%$ across 20 different countries. ${ }^{4}$

In Malaysia, the NHMS in 2011 reported the prevalence of physical inactivity among adults aged 18 years and above in Malaysia was $35.2 \%{ }^{5}$, while the same NHMS in 2015 reported a slightly reduction in the prevalence of physical inactivity with $33.1 \%{ }^{6}$

By monitoring the current level of physical inactivity and identifying the high-risk group among populations, effective and targeted strategies or programmes can be developed along with supporting evidence-based policy making by stakeholder. Therefore, this study aimed to determine the prevalence of physical inactivity and its associated factors among adults aged 18 years and above in Malaysia.

\section{METHODS}

Study Sample

This study was part of the National Health and Morbidity Survey (NHMS) 2019 which focused on the non-communicable diseases and their risk factors in Malaysia. It is a cross-sectional, population-based survey with complex study design using a two-stage stratified random sampling to select representative s amples of adults aged 18 years and above in Malaysia. The stratifications were performed by including all states and federal territories in Malaysia as primary stratumand the urban/ rural localities as secondary stratum. The Primary Sampling Unit (PSU) are Enumeration Blocks (EBs) selected by Department of Statistics Malays ia according to updated National Population and Housing Census 2010. A total of 475 EBs were randomly selected across Malaysia by proportionate to population size in each state. Subsequently, Secondary Sampling Unit (SSU) which is a total of 12 Living Quarters (LQs) were randomly selected from each selectedEB. Finally, all individuals aged 18 years and above residing in the selected LQs for at least two weeks prior to data collection were included in the sample. Institutional populations such as hotels, hostels, hospitals, old folk homes and others were not included in the survey. The detail methodology can be referred in National Health and Morbidity Survey (NHMS) 2019 Technical Report Volume I in http://iku.moh.gov.my/nhms-2019. ${ }^{7}$

\section{Data Collection}

The data collection was conducted via face- to-face interviews from July to September 2019 by trained interviewers.

All eligible respondents were provided with written person information sheet and consent form before any interview. This study protocol was approved by the Medical Review and Ethics Committee (MREC), Minis try ofHealth, Malaysia.

Instrument

For this survey, physical activity ass essment was determined using a validated Malay version of short form International Physical Activity Questionnaire (IPAQ). ${ }^{8}$

Based on Guidelines for Data Processing and Analysis of IPAQ ${ }^{9}$, intensity of physical activity was calculated using a Metabolic Equivalents (METs ) score. One MET was defined as the energy cost of sitting quietly, which is relative to the resting metabolic rate, thus equivalent to a caloric consumption of $1 \mathrm{kcal} / \mathrm{kg} /$ hour. MET-minutes were calculated by multiplying the MET score of an activity (3.3 METs for walking, 4.0 METs for moderate- intensity physical activity and 8.0 METs for vigorous-intensity physical activity) with the minutes per sessions and number of days performed. ${ }^{9}$ Total physical activity level of an individual was computed by summation of METminutes/week from walking, moderate-intensity and vigorous-intensity physical activity.

An individual with any combination of total score from walking, moderate-intensity physical activity or vigorous-intensity physical activity which is lower than 600 MET minutes per week was considered as physically inactive.

Variable Definitions

In this study, low hous ehold income group is the combination of Q1 and Q2 income groups while Q3 and Q4 is grouped together as the middle-income group. High household income is the Q5 income group.

The respondents were categorized into presence or absence of comorbidities according to their self-reported information as diagnosed by a doctor or health professional. The respondents were 
asked to answer "yes" or "no" to this question, "Have you ever been told by a doctor or Assistant Medical Officer that you have diabetes, hypertension or hypercholesterolaemia?". If they answered "no", their status of comorbidities was classified according to their finger prick blood test. Res pondents was classified as having diabetes when their fas ting blood sugar (FBS) were $7.0 \mathrm{mmol} / \mathrm{L}$ or more or randomblood sugar(RBS) were more than $11.1 \mathrm{mmol} / \mathrm{L}$. Res pondents were classified as having hypertension when their systolic blood pressure was $140 \mathrm{mmHg}$ or more and/ or diastolic blood pressure of $90 \mathrm{mmHg}$ or more. Respondents with hypercholesterolaemia had a total blood cholesterol of $6.2 \mathrm{mmol} / \mathrm{L}$ or more. For anaemia status, haemoglobin level was measured using HemoCue $\mathrm{Hb} 201+$. Anaemic respondents were classified based on 2011 haemoglobin cut-off by World Health Organization. ${ }^{10}$ The Body Mass Index (BMI) were categorized into four categories as classified by WHO 1998; underweight $\left(<18.5 \mathrm{~kg} / \mathrm{m}^{2}\right)$, normal $\left(18.5-24.9 \mathrm{~kg} / \mathrm{m}^{2}\right)$, overweight $\left(25.0-29.9 \mathrm{~kg} / \mathrm{m}^{2}\right)$ and obese $\left(\geq 30.0 \mathrm{~kg} / \mathrm{m}^{2}\right){ }^{11}$

Data analys is

Data analysis was done using complex sample analysis. Multiple logistic regression analyses were performed to analyse the crude and adjusted odd ratios (ORs) with $95 \%$ confidence interval(CI). Any variable with $p$-value of less than 0.25 in the univariable analysis was included in the final multivariable logistic regression model. The statistical significance level was set at 0.05 . All statistical analyses were performed using SPSS version 25 .

\section{RESULTS}

A total of 10,356 out of 10,472 respondents aged 18 years and above answered the Physical Activity Module in this survey completely, giving a response rate of $98.9 \%$.

Overall, the prevalence of physical inactivity among adults aged 18 years and above in Malaysia was $24.6 \%$ (95\% CI: 23.2, 26.1). Table 1 shows that females were more physically inactive compared to male. Physical inactivity was higher among elderly aged 60 years and above. By ethnicity, Chinese population was the most physically inactive ethnic group. Urban dwellers were also more physically inactive compared to rural dwellers. Furthermore, physical inactivity was more prevalent among those with tertiary education compared to lower education level, and those who were single, unmarried, widow, widower or divorcee compared to married. Students tend to be the most inactive group compared to other occupation categories. According to household income, physical inactivity was the highest among the high household income group.

Physical inactivity was highest among adults with comorbidity. The prevalence of physical inactivity was higher among adults with diabetes, hypertension, hypercholesterolaemia and anaemia. By BMI status, underweight adults (BMI less than 18.5) were the most inactive group compared to other BMI categories.

Table 1 Prevalence of Physical Inactivity among Adults Aged 18 Years and Above in Malaysia ( $\mathrm{n}=10,356)$

\begin{tabular}{|c|c|c|c|c|c|c|}
\hline \multirow{2}{*}{ Variables } & \multirow{2}{*}{$\begin{array}{l}\text { Estimated } \\
\text { Population }\end{array}$} & \multirow{2}{*}{$\begin{array}{l}\text { Unweighted } \\
\text { Count (n) }\end{array}$} & \multirow{2}{*}{$\begin{array}{l}\text { Prevalance } \\
(\%)\end{array}$} & \multicolumn{2}{|c|}{$95 \% \mathrm{CI}$} & \multirow[b]{2}{*}{ p-value } \\
\hline & & & & Lower & Upper & \\
\hline Overall & $5,180,717$ & 2,668 & 24.6 & 23.2 & 26.1 & \\
\hline Sex & & & & & & $<0.001$ \\
\hline Female & $2,870,486$ & 1,558 & 27.9 & 25.9 & 30.0 & \\
\hline Male & $2,310,232$ & 1,110 & 21.5 & 19.8 & 23.4 & \\
\hline Age Group (Years) & & & & & & $<0.001$ \\
\hline $18-39$ & $2,802,585$ & 1,084 & 24.1 & 22.1 & 26.1 & \\
\hline $40-59$ & $1,198,892$ & 698 & 19.0 & 17.3 & 21.0 & \\
\hline$\geq 60$ & $1,179,241$ & 886 & 38.3 & 35.1 & 41.6 & \\
\hline Ethnicity & & & & & & $<0.001$ \\
\hline $\begin{array}{l}\text { Malay (including Orang } \\
\text { Asli) }\end{array}$ & $2,698,799$ & 1,801 & 25.0 & 23.4 & 26.7 & \\
\hline Chinese & $1,456,457$ & 407 & 32.4 & 28.8 & 36.2 & \\
\hline Indian & 315,178 & 177 & 25.5 & 20.8 & 30.8 & \\
\hline $\begin{array}{l}\text { Bumiputera of Sabah or } \\
\text { Sarawak }\end{array}$ & 490,635 & 206 & 21.6 & 18.4 & 25.2 & \\
\hline Others & 219,651 & 77 & 9.9 & 6.5 & 14.9 & \\
\hline Locality & & & & & & $<0.001$ \\
\hline Urban & $4,255,418$ & 1,741 & 25.9 & 24.2 & 27.7 & \\
\hline Rural & 925,300 & 927 & 20.1 & 17.8 & 22.7 & \\
\hline Education & & & & & & $<0.001$ \\
\hline No Formal Education & 313,585 & 234 & 29.3 & 24.2 & 27.7 & \\
\hline Primary Education & 996,493 & 648 & 24.6 & 21.6 & 28.0 & \\
\hline
\end{tabular}


International Journal of Public Health Research Vol 12 No 1 2022, pp(1536-1544)

\begin{tabular}{|c|c|c|c|c|c|c|}
\hline Secondary Education & $2,273,272$ & 1,101 & 22.2 & 20.5 & 24.1 & \\
\hline Tertiary Education & $1,564,013$ & 668 & 28.1 & 25.5 & 30.9 & \\
\hline \multicolumn{6}{|l|}{ Marital Status } & \multirow[t]{3}{*}{$<0.001$} \\
\hline $\begin{array}{l}\text { Single/Widow(er)/ } \\
\text { Divorcee }\end{array}$ & $2,178,040$ & 1,040 & 29.2 & 26.9 & 31.7 & \\
\hline Married & $3,002,678$ & 1,628 & 22.1 & 20.5 & 23.9 & \\
\hline \multicolumn{6}{|l|}{ Occupation } & \multirow[t]{9}{*}{$<0.001$} \\
\hline Government employee & 343,434 & 248 & 22.2 & 17.9 & 27.2 & \\
\hline Private employee & $1,678,578$ & 618 & 20.7 & 18.4 & 23.2 & \\
\hline Self employed & 579,782 & 283 & 16.1 & 13.4 & 19.2 & \\
\hline Retiree & 233,253 & 150 & 29.8 & 24.0 & 36.3 & \\
\hline Student & 320,755 & 115 & 42.9 & 35.4 & 50.8 & \\
\hline Unpaid worker/ & & & & & & \\
\hline $\begin{array}{l}\text { Homemaker/ Caregiver/ } \\
\text { Not }\end{array}$ & $2,021,502$ & 1,253 & 32.6 & 30.1 & 35.2 & \\
\hline $\begin{array}{l}\text { (unemployed, health } \\
\text { problem, old age) }\end{array}$ & & & & & & \\
\hline \multicolumn{6}{|l|}{ Hous ehold Income } & \multirow[t]{4}{*}{0.004} \\
\hline Low & $1,730,505$ & 1,024 & 22.4 & 20.2 & 24.7 & \\
\hline Middle & $1,848,980$ & 856 & 24.4 & 22.2 & 26.7 & \\
\hline High & $1,195,293$ & 561 & 27.0 & 23.7 & 30.6 & \\
\hline \multicolumn{6}{|l|}{ Diabetes } & \multirow{3}{*}{$<0.001$} \\
\hline Yes & $1,161,676$ & 796 & 30.4 & 27.8 & 33.1 & \\
\hline No & $4,011,371$ & 1,869 & 23.3 & 21.8 & 25.0 & \\
\hline \multicolumn{6}{|l|}{ Hypertension } & \multirow[t]{3}{*}{$<0.001$} \\
\hline Yes & $1,782,426$ & 1,175 & 28.3 & 26.3 & 30.5 & \\
\hline No & $3,388,013$ & 1,489 & 23.0 & 21.3 & 24.8 & \\
\hline \multicolumn{6}{|l|}{ Hypercholesterolaemia } & \multirow[t]{3}{*}{$<0.001$} \\
\hline Yes & $1,347,174$ & 875 & 29.5 & 27.3 & 31.8 & \\
\hline No & $3,825,873$ & 1,790 & 23.3 & 21.7 & 25.0 & \\
\hline \multicolumn{6}{|l|}{ Anaemia } & \multirow[t]{3}{*}{0.009} \\
\hline Anaemic & $1,185,163$ & 714 & 28.0 & 25.2 & 31.1 & \\
\hline Not anaemic & $3,674,494$ & 1,823 & 23.5 & 21.8 & 25.2 & \\
\hline \multicolumn{6}{|l|}{ BMI Status } & \multirow[t]{5}{*}{0.032} \\
\hline Underweight & 371,211 & 170 & 28.7 & 23.7 & 34.2 & \\
\hline Normal & $2,012,392$ & 906 & 23.5 & 21.4 & 25.9 & \\
\hline Overweight & $1,261,081$ & 724 & 21.1 & 19.1 & 23.2 & \\
\hline Obese & 875,081 & 495 & 22.6 & 20.0 & 25.5 & \\
\hline
\end{tabular}

Table 2 shows that according to age group, adults aged $40-59$ years (aOR 0.72 ; $95 \%$ CI: 0.59 , 0.88 ) were less likely to be inactive compared to age group 18 - 39 years old. Chinese (aOR 1.32; $95 \%$ CI: $1.04,1.67)$ were more likely to be physically inactive compared to the Malays (including Orang Asli). Physical inactivity was significantly higher among urban dwellers (aOR 1.30; 95\% CI: 1.07, 1.57), single adults including widow or widower and divorcee (aOR 1.36; 95\% CI: 1.14, 1.61). Students (aOR 2.10; 95\% CI: 1.30, 3.40) were the most likely to be inactive among the occupation category. Adults with high income which is in Quintile 5 income group were 1.34 times (aOR 1.34; 95\% CI: $1.07,1.68)$ more inactive compared to other income groups. Based on non-communicable disease status, adults with hypercholesterolaemia (aOR 1.25; 95\% CI: $1.03,1.51)$ were more likely to be physically inactive compared to non-hypercholesterolaemia adults. However, there is no significant association between physical inactivity and BMI status.

Table 2 Factors Associated with Physical Inactivity among Adults Aged 18 Years and Above in Malaysia (n= $10,356)$

\begin{tabular}{|c|c|c|c|c|c|c|c|c|}
\hline \multirow{3}{*}{ Variables } & \multicolumn{4}{|c|}{ CRUDE OR } & \multicolumn{4}{|c|}{ ADJUSTEDOR } \\
\hline & \multirow{2}{*}{ OR } & \multicolumn{2}{|c|}{$95 \%$ CI } & \multirow{2}{*}{ p-value } & \multirow{2}{*}{ OR } & \multicolumn{2}{|c|}{$95 \% \mathrm{CI}$} & \multirow{2}{*}{ p-value } \\
\hline & & Lower & Upper & & & Lower & Upper & \\
\hline Sex & 141 & 123 & & $<0001$ & 114 & 094 & 137 & 0177 \\
\hline $\begin{array}{l}\text { Female } \\
\text { Male }\end{array}$ & $\begin{array}{l}1.41 \\
\operatorname{Ref}\end{array}$ & 1.23 & 1.62 & $<0.001$ & $\begin{array}{l}1.14 \\
\operatorname{Ref}\end{array}$ & & & \\
\hline
\end{tabular}


Age Group (Years)

$18-39$
$40-59$
$\geq 60$

Ethnicity

Malay (including Orang Ref

Asli)

Chinese

Indian

Bumiputera of Sabah or

Sarawak

Locality

Others

Urban

Rural

Education

No Formal Education

Primary Education

Secondary Education

Tertiary Education

Ref

0.74

1.96

0.64

1.65

0.86

2.32

$<0.001$

$<0.001$

1.44

1.03

0.83

0.33

1.19

0.78
0.67

1.75

1.35

1.03

$<0.001$

0.853

0.089

0.53

$<0.001$

1.65

$1.39 \quad 1.16$

Ref

1.06

0.84

0.73

Ref

Marital Status

Single/ Widow(er)/ 1.45
Divorcee

Married

Occupation

Government employee
Private employee
Self employed
Retiree
Student
Unpaid worker/
Homemaker/ Caregiver/
Not working
(unemployed, health
problem, old age)

Ref

Ref

0.91

0.67

1.49

2.63

1.69

0.78

0.68

0.62

1.43

1.04

0.86

0.102

$<0.001$

1.68

$<0.001$

1.26

1.68

.

1.36

1.14

Ref

Ref

0.68

1.23

0.95

0.540

0.023

0.045

$<0.001$

$<0.001$

3.99

2.27

1.74
1.26

Ref

Low

Middle

High

Diabetes

Yes

No

Hypertension

Yes

No

Hypercholesterolaemia

Yes

No

Anaemia

Anaemic

Not anaemic

BMI Status

Underweight

Normal

Overweight

Obese
1.12

1.28

0.94

1.03

1.34

1.61

0.218

0.028

1.43

Ref

1.24

1.66

$<0.001$

1.32

1.15

1.51

$<0.001$

1.58

$\begin{array}{ll}1.38 & 1.20\end{array}$

Ref

$1.27 \quad 1.06$

1.52

0.009

Ref

$1.31 \quad 1.00$

1.71

Ref

0.87

0.95

0.75

0.78

$\begin{array}{ll}1.01 & 0.069\end{array}$

$1.16 \quad 0.615$

0.053
0.90

0.71

1.03

2.10

1.32

0.67

0.50

0.64

1.30

0.95

1.22

1.01

0.501

1.66

0.056

3.40

0.902

1.83

0.096

DISCUSSION

The prevalence of physical inactivity among adults aged 18 years and above in Malaysia was 24.6\%. By comparing to the other study which used the IPAQ among 18-65 years old, physical inactivity among adults in Malaysia was higher compared to China 
(6.9\%), India (23.4\%), Hong Kong (15.3\%; age 2064 years); but lower compared to Japan $(43.3 \%$; age 18-39 years) and Taiwan $(42.3 \%)^{4}$

In this study, there was no significant difference in physical inactivity between males and females which suggesting gender equity in physical activity. Gender equity practice fair allocation of resources and opportunities for both females and males, eliminate discrimination that are barrier of full participant of either gender and to provide all individuals with access and opportunity to almost all activities. ${ }^{12}$ By age group, older adults aged 40-59 years old were less likely to be physically inactive compared to younger adults aged 18-39 years old. Total energy expenditure might decline significantly with age but the level of physical activity appears to be maintained from young adulthood until reaching upper- middle age suggesting our present environment is quite sedentary for young people or the physical activity is maintained throughout adulthood and retirement years before declining as ageing progress. ${ }^{13}$ Physical activity in adolescent is an important contributing factor towards level of physical activity during adults and subsequently can affect adult's health. ${ }^{14}$

Chinese ethnic group was more likely to be physically inactive compared to other ethnicities, similar as reported by NHMS 2011..$^{5}$ A study by Lian et al showed that there was a significant negative relationship between the Chinese ethnic group and physical activity, indicating that the Chinese population have less engagement in physical activity compared to other ethnicities. ${ }^{15}$ Their engagement in light, moderate and vigorous physical activity is very low compared to other ethnicities suggesting some normative aspects of Malaysian Chinese culture that discourage exercise. ${ }^{15}$ Chinese origin among Asia were consistently found to have lower level of exercise than other origins as they considered exercise as play, thus less priority than studying hard and physical activity in educational policy. ${ }^{16}$ By locality, urban dwellers showed a higher level of physical inactivity compared to rural dwellers because of stressful lifestyle ${ }^{17}$ or high travelling cost for longer distance physical activity facility or setting ${ }^{18}$, thus les s devoted time and engaging in physical activity.

Those who were single were more likely to be physically inactive than the married adults. Family relationships posed an important role in motivating them to participate in physical activity. ${ }^{19}$ Having children increases the probability of adults to be physically active, but decreasing about three to five minutes of time spent on physical activity for each additional child in the hous ehold. ${ }^{20}$ Findings also showed that student (may referred to college students, university students, or anyone those further their study or advanced studies) were the most physically inactive groups. Studies showed that the rate of physical activity during college years was lower than the rate of physical activity during the high school years. ${ }^{21}$ A study among 145 Canadian univers ity undergraduates showed that $62.2 \%$ of the students were active during the last two months of their high school but decreasing to $44 \%$ in their first two months in university. ${ }^{22}$

Our study showed that the higher the level of hous ehold income, the less likely that persons to be physically active. Higher household income earners tend to substitute working for leisure-time physical activity, causing a more sedentary lifestyle. ${ }^{23}$ A study using Behavioral Risk Factor Surveillance System (BRFSS) showed that a $\$ 10,000$ increase in income peryear associated with a decreasing of 8 to 41 minutes time spent in physical activity per week. ${ }^{20,23}$ A study on relationship of income and physical activity using NHMS 2011 data showed that there is a reduction of 0.011 minutes per week in time spent in vigorous and moderate physical activity with an additional unit of income. ${ }^{24}$ In Malaysia, all individual residents were eligible a maximum of RM2500 tax relief by Inland Revenue Board of Malaysia with purchase of sports equipment for any sports activity as defined under the Sports Development Act 1997 and payment of gym membership. This should encourage the higher income earners to do more physical activity, hence increasing their intensity and duration of doing it.

Phys ical inactivity was significantly higher among those with hypercholesterolaemia. A study among communities in Sarawak showed that there is an association between blood cholesterol with physical inactivity. ${ }^{25}$ There is a reduction in physical activity associated with increasing numbers of chronic conditions including diabetes, heart disease and effects of a stroke. ${ }^{26}$ The Medical Expenditure Panel Survey (MEPS) for the U.S. population showed that prevalence of moderate or vigorous physical inactivity were higher among diabetic adults; also a higher prevalence of physical inactivity among those with diabetes and hyperlipidaemia. ${ }^{27}$ A systematic review showed that there is a weak to moderate evidence to support association of sedentary lifestyle and unhealth eating patterns with cardio-metabolic risk among Malaysian adolescents ${ }^{28}$, which will subsequently indicate their future negative health consequences. Thus, intervention in adolescents/children are not only effective and cost effective, but also improve children's quality of life and may reduce lipid related risk to their health in adulthood. ${ }^{29} \mathrm{~A}$ high level of physical fitness and/ or physical activity during adolescence and young adulthood can be predictive for a healthy cardiovascular risk profile later in life. ${ }^{30}$

These findings may be limited by the measurement of the METs that focusing on sports or exercise that may lead to underestimate or overestimate of level of physical activity. Females 
always as sociated with habitual movements such as doing household chores or as a family care taker, with more time for home activity than physical activity. ${ }^{23}$ Future study should be done by different objective measured, for example by assessing methods and analys is of energy expenditure to determine the intensity level rather than grouping into intensity group.

The self-reported physical activity also might introduce recall bias. However, this study provided the best nationally representative data on physical activity using validated tools.

\section{CONCLUSION}

There is a crucial need to create specific and appropriate intervention programmes towards specific targeted group such as Chinese, urban dwellers, adults who were single, students, higher income earners and those who have hypercholesterolaemia to increase their levels of physical activity. An active living for population good health and wellbeing should be promoted, towards an active and healthy Malaysia as vis ion in National Strategic Plan for Active Living (NASPAL) 2017 - 2025 in order to achieve targets by the Sustainable Development Goals (SDG) 2030.

\section{ACKNOWLEDGEMENT}

The authors would like to thank the Director General of Health Malaysia for his permis sion to publish this article. We would also like to thank all those who were involved in this study for their contributionand commitment throughout the study.

\section{REFERENCES}

1. World Health Organization. Global Recommendations on Physical Activity for Health [Internet]. 2010 [cited 2020 June 15]. Available from: https:/www.who.int/publications/i/item/glo bal-recommendations-on-physical-activityfor-health.

2. Lee IM, Shiroma EJ, Lobelo F, Puska P, Blair SN, Katzmarzyk PT, et al. Effect of physical inactivity on major noncommunicable diseases worldwide: An analysis of burden of disease and life expectancy. Lancet [Internet]. 2012 [cited 2020 July 17];380(9838):219-29. Available from: http://dx.doi.org/10.1016/S01406736(12)61031-9.

3. Guthold R, Stevens GA, Riley LM, Bull FC. Worldwide trends in insufficient physical activity from 2001 to 2016: a pooled analys is of 358 population-based surveys with 1.9 million participants. Lancet Glob Heal [Internet]. 2018 [cited 2020 January 24];6(10):e1077-86. Available from: http://dx.doi.org/10.1016/S2214109X(18)30357-7.
4. Bauman A, Bull F, Chey T, Craig CL, Ainsworth BE, Sallis JF, et al. The international prevalence study on physical activity: Results from 20 countries. Int J Behav Nutr Phys Act [Internet]. 2009 [cited 2020 July 15]; 6:1-11. Available from https://ijbnpa.biomedcentral.com/track/pdf/ 10.1186/1479-5868-6-21.pdf.

5. Teh $\mathrm{CH}, \operatorname{Lim} \mathrm{KK}$, Chan YY, Lim KH, Azahadi O, Hamizatul Akmar AH, et al. The prevalence of physical activity and its ass ociated factors among Malaysian adults: Findings from the National Health and Morbidity Survey 2011. Public Health [Internet]. 2014 [cited 2020 January 24]; 128(5):416-23. Available from: http://dx.doi.org/10.1016/j.puhe.2013.10.00 8.

6. Chan YY, Lim KK, Lim KH, Teh CH, Kee $\mathrm{CC}$, Cheong SM, et al. Physical activity and overweight/obesity among Malaysian adults: Findings from the 2015 National Health and morbidity survey (NHMS). BMC Public Health [Internet]. 2017 [cited 2020 January 24];17(1):1-12. Available from:

https://bmcpublichealth.biomedcentral.com /track/pdf/10.1186/s 12889-017-4772-z.pdf.

7. Institute for Public Health, National Institutes of Health, Ministry of Health Malaysia. National Health and Morbidity Survey (NHMS) 2019: Vol I: NCDs- NonCommunicable Dis eases: Risk Factors and other Health Problems. [Internet]. 2020 [cited 2020 Aug 11]. Available from: http://iku.moh.gov.my/nhms-2019.

8. Chu AHY, Moy FM. Reliability and validity of the malay international physical activity questionnaire (IPAQ-M)among a malay population in Malaysia. Asia-Pacific $\mathbf{J}$ Public Heal [Internet]. 2015 [cited 2020 January 24]; 27(2):NP2381-9. Available from:

https://pubmed.ncbi.nlm.nih.gov/22593217 l.

9. IPAQ Research Committee. Guidelines for Data Processing and Analysis of the International Physical Activity Questionnaire ( IPAQ ) - Short and Long Forms. [Internet]. 2005 [cited 2020 January 24]; 1-15. Available from: https://sites.google.com/site/theipaq/.

10. World Health Organization. Iron Deficiency Anaemia Assessment, Prevention, and Control: A guide for programme managers [Internet]. 2001 [cited 2020 June 17]. Available from https://www.eldis.org/document/A44286.

11. World Health Organization. Obesity: Preventing And Managing The Global 
Epidemic [Internet]. 2000. [cited 2020 August 11]. Available from https://www.researchgate.net/publication/2 71745811 Obesity Preventing and Mana ging_the_Global_Epidemic_Report_of_a WHO_Consultation_WHO_Technical_Rep ort_Series_894_Pp_252_World_Health_Or ganization Geneva 2000 SFr 5600 ISBN 92-4-120894-5 paperback.

12. International Working Group on Women and Sport. The Montreal Tool Kit: A legacy of 2002 World Conference [Internet]. 2002 [cited 2020 June 17]. Available from https://www.icsspe.org/system/files/2002 World Conference on Women and Sport Montreal Toolkit.pdf.

13. Johannsen DL, DeLany JP, Frisard MI, Welsch MA, Rowley CK, Fang X, et al. Physical activity in aging: Comparison among young, aged, and nonagenarian individuals. J Appl Physiol [Internet]. 2008 [cited 2020 June 17]; 105(2):495-501. Available from: https://journals.physiology.org/doi/full/10.1 152/japplphysiol.90450.2008.

14. Dumith SC, Gigante DP, Domingues MR, Hallal PC, Menezes AMB, Kohl HW. Predictors of physical activity change during adolescence: A 3·5-year follow-up. Public Health Nutr [Internet]. 2012 [cited 2020 July 15]; 15(12):2237-45. Available from:

https://www.cambridge.org/core/journals/p ublic-health-nutrition/article/predictors-ofphysical-activity-change-during-

adolescence-a-35year-

followup/6751701A49DF9F4952AD6352B 3BE422C.

15. Lian TC, Bonn G, Han YS, Choo YC, Piau WC. Physical activity and its correlates among adults in Malaysia: A cross-sectional descriptive study. PLoS One [Internet]. 2016 [cited 2020 January 24]; 11(6):1-14. Available from: https://journals.plos.org/plosone/article?id= 10.1371/journal.pone.0157730.

16. Callaghan P, Eves FF, Norman P, Chang AM, Lung CY. Applying the Transtheoretical Model of Change to exercise in young Chinese people. $\mathrm{Br} \mathrm{J}$ Health Psychol[Internet]. 2002 [cited 2020 July 17]; 7(3):267-82. Available from: https://bpspsychub.onlinelibrary.wiley.com /doi/abs/10.1348/135910702760213670.

17. Cheah YK. Socioeconomic disparities in physical activity participation: An exploratory study using malay sample. Asia-Pacific Soc Sci Rev [Internet]. 2015 [cited 2020 June 24]; 15(2):93-107. Available from: http://apssr.com/volume- 15-no-2/socioeconomic-dis parities-inphysical-activity-participation-anexploratory-study-using-malay-sample/.

18. Ruseski JE, Humphreys BR, Hallmann K, Breuer C. Family structure, time constraints, and sport participation. Eur Rev Aging Phys Act [Internet]. 2011 [cited 2020 June 26]; 8(2):57-66. Available from: $\mathrm{https}: / /$ eurapa.biomedcentral.com/articles/1 0.1007/s 11556-011-0084-y.

19. Jepson R, Harris FM, Bowes A, Robertson R, Avan G, Sheikh A. Physical Activity in South Asians: An In-Depth Qualitative Study to Explore Motivations and Facilitators. PLoS One [Internet]. 2012 [cited 2020 June 29]; 7(10). Available from https://journals.plos.org/plosone/article?id= 10.1371/journal.pone.0045333.

20. Humphreys BR, Ruseski JE. An economic analys is of participation and time spent in physical activity. BE J Econ Anal Policy [Internet]. 2011 [cited 2020 June 29]; 11(1). Available from: https://www.degruyter.com/document/doi/1 0.2202/1935-1682.2522/html.

21. Mohammed G, Md Said S, Azuhairi, Ariffin A, Kamaruzaman J. Physical Inactivity and Its Associated Factors among University Students. IOSR J Dent Med Sci [Internet]. 2014 [cited 2020 June 24]; 13(10):119-30. Available from: https://www.iosrjournals.org/iosr$\mathrm{jdms} /$ papers/Voll3-issue10/Version1/S013101119130.pdf.

22. Sinclair K, Hamlin M, Steel Gd. Physical activity levels of first-year New Zealand university students - a pilot study. Youth Stud Aust [Internet]. 2005 [cited 2020 Jun 24]; 24(1):38-42. Available from: https://www.semanticscholar.org/paper/Phy sical-Activity-Levels-of-First-year-NewZealand-Sinclair-

Hamlin/9d6cf7cbf8b2553e3bdb3afc36bb83 c40145967e.

23. Cheah YK, Poh BK. The Determinants of Participation in Physical Activity in Malaysia. Osong Public Heal Res Perspect [Internet]. 2014 [cited 2020 June 29]; 5(1):20-7. Available from: http://dx.doi.org/10.1016/j.phrp.2013.12.00 2.

24. Cheah YK, Azahadi M, Phang SN, Abd Manaf NH. The income elasticity of participation in physical activity: Evidence from Malays ia. Int J Econ Manag [Internet]. 2017 [cited 2020 July 06]; 11(2):321-34. Available from: http://www.jjem.upm.edu.my/voll1_no2/(3 )THE\%20INCOME\%20ELASTICITY\%20 OF\%20PARTICIPATION\%20IN\%20PHY 
SICAL\%20ACTIVITY.pdf.

25. Lian CW, Hazmi H, Thon CC, Muda WMW. Physical activity and cardiovascular risk factors among Malays in selected rural and urban communities in Sarawak. Malaysian J Public Heal Med [Internet]. 2015 [cited 2020 July 06]; 15(3):104-11. Available from: https://www.mjphm.org.my/mjphm/index.p hp?option=com_content\&view=article\&id $=648$ :physical-activity-and-cardiovascularrisk-factors-among-malays-in-selectedrural-and-urban-communities-in-

sarawak\&catid=102:2015-volume-15$3 \&$ Itemid $=118$.

26. Kaplan MS, Newsom JT, McFarland BH, $\mathrm{Lu}$ L. Demographic and psychosocial correlates of physical activity in late life. Am J Prev Med [Internet]. 2001 [cited 2020 July 06]; 21(4):306-12. Available from: https://www.sciencedirect.com/science/arti cle/abs/pii/S0749379701003646.

27. Sullivan PW, Morrato EH, Ghushchyan V, Wyatt HR, Hill JO. Obesity, inactivity, and the prevalence of diabetes and diabetesrelated cardiovascular comorbidities in the U.S. 2000-2002. Vol. 28, Diabetes Care [Internet]. 2005 [cited 2020 July 06]; p. 1599-603. Available from: https://care.diabetesjournals.org/content/28/ $7 / 1599$.

28. Mohammadi S, Jalaludin MY, Su TT, Dahlui M, Mohamed MNA, Majid HA. Dietary and physical activity patterns related to cardio-metabolic health among Malaysian adolescents: A systematic review. BMC Public Health [Internet]. 2019 [cited 2020 July 06]; 19(1). Available from: https://bmcpublichealth.biomedcentral.com /articles/10.1186/s 12889-019-6557-z.

29. Park, YMM. Sui, X. Liu, J. Zhou, H. Kokkinos, PF. Lavie, CJ. Hardin, JW. Blair $\mathrm{S}$. The effect of card iores piratory fitness on age-related lipids and lipoproteins. J Am Coll Cardiol [Internet]. 2015 [cited 2020 July 17]; 65(19):2091-100. Available from: https://pubmed.ncbi.nlm.nih.gov/25975472 /.

30. Twisk JWR, Kemper HCG, Van Mechelen W. Prediction of cardiovascular disease risk factors later in life by physical activity and phys ical fitness in youth: General comments and conclusions. Int J Sport Med Suppl [Internet]. 2002 [cited 2020 July 17]; 23(1). Available from: https://www.thiemeconnect.com/products/ejournals/abstract/10 $.1055 / \mathrm{s}-2002-28461$. 